\title{
Therapeutic group in mental health: intervention in the family health strategy
}

\author{
Grupo terapêutico em saúde mental: percepção de usuários na atenção básica \\ Grupo terapéutico en salud mental: intervención en la estrategia salud de la familia
}

\section{Naipy Abreu Brunozia Samanta Silva Souza ${ }^{a}$ Cíntia Rosa Sampaio ${ }^{a}$ Suellen Rodrigues de Oliveira Maier ${ }^{b}$ Lilian Carla Vieira Gimene Silva ${ }^{a}$ ii Graciano Almeida Sudréa}

How to cite this article: Brunozi NA, Saouza SS, Sampaio CR, Maier SRO, Silva LCVG, Sudré GA. Therapeutic group in mental health: intervention in the family health strategy. Rev Gaúcha Enferm. 2019:40:e20190008. doi: https://doi.org/10.1590/19831447.2019.20190008

\footnotetext{
Universidade Federal de Mato Grosso (UFMT), Campus Universitário de Rondonópolis. Residência Multiprofissional em Saúde da Família. Rondonópolis, Mato Grosso, Brasil.

${ }^{b}$ Universidade Federal de Mato Grosso (UFMS), Campus Universitário de Rondonópolis. Residência Multiprofissional em Saúde do Adulto e Idoso. Rondonópolis, Mato Grossso, Brasil.
}

\section{ABSTRACT}

Objective: To understand the perception of primary care users in the face of mental suffering and participation in a coexistence therapeutic group.

Methods: Convergent Care Research of qualitative approach performed with four participants of a therapeutic group in a Family Health Strategy. Was used the semi-structured interview, carried out in February 2018, and the software Interface de R pour les Analyses Multidimensionnelles de Textes et de Questionnaires for coding the data.

Results: The therapeutic group in mental health can contribute to the reduction of stigma related to mental illness and to promotion and prevention in mental health, using relational technologies, low-cost and accessible for professionals.

Conclusion: The study contributed to inspire new actions and revitalize mental health practices through an intervention that can be implemented and that can bring benefits to those involved in the context of Primary Care.

Keywords: Primary health care. Stress, psychological. Mental health assistance. Therapeutics. Group structure.

\section{RESUMO}

Objetivo: Compreender a percepção de usuários da atenção básica diante do sofrimento mental e da participação em um grupo terapêutico de convivência.

Métodos: Pesquisa Convergente Assistencial de abordagem qualitativa realizada com quatro participantes de um grupo terapêutico em uma Estratégia Saúde da Família. Foi utilizada a entrevista semiestruturada, realizadas em fevereiro de 2018, e o software Interface de $R$ pour les Analyses Multidimensionnelles de Textes et de Questionnaires para codificação dos dados.

Resultados: 0 grupo terapêutico em saúde mental pode contribuir para a redução do estigma relacionado ao adoecimento mental e para promoção e prevenção em saúde mental utilizando como principais ferramentas tecnologias relacionais de cuidado, de baixo custo e acessíveis aos profissionais.

Conclusão: 0 estudo contribuiu para inspirar novas ações e revitalizar práticas de saúde mental por meio de uma intervenção passível de ser implementada e que pode trazer benefícios aos envolvidos no contexto da Atenção Básica.

Palavras-chave: Atenção primária à saúde. Estresse psicológico. Assistência à saúde mental. Terapêutica. Estrutura de grupo.

\section{RESUMEN}

Objetivo: Comprender la percepción de los usuarios de la atención básica ante el sufrimiento mental y la participación en un grupo terapéutico de convivencia.

Métodos: Investigación Convergente Asistencial de abordaje cualitativo realizada con cuatro participantes de un grupo terapéutico en una Estrategia de Salud Familiar. Se utilizó la entrevista semiestructurada, realizada en febrero de 2018, y el software Interface de R pour les Analyses Multidimensionnelles de Textes et de Questionnaires para codificación de los datos.

Resultados: El grupo terapéutico en salud mental puede contribuir a la reducción del estigma relacionado con la enfermedad mental y para la promoción y prevención en salud mental utilizando como principales herramientas técnicas relacionales de cuidado, de bajo costo y accesibles a los profesionales.

Conclusión: El estudio contribuyó a inspirar nuevas acciones y revitalizar prácticas de salud mental a través de una intervención pasible de ser implementada y que puede traer beneficios a los involucrados en el contexto de la Atención Básica.

Palabras clave: Atención primaria de salud. Estrés psicológico. Atención a la salud mental. Terapéutica. Estructura de grupo. 


\section{口INTRODUCTION}

The movement of the Psychiatric Reform (PR) gained momentum in the mid-1970s and 1980s, contemporary to the sanitary movement that culminated in the creation of the Unified Health System ("SUS"). PR is a complex social movement that arouses critical thinking contrary to institutionalizing madness and the psychiatric paradigm based on social exclusion; with it, emerged the prospect of creating services with innovative and alternative practices to the predominant hospital model and asylum practices, where serious human rights violations occurred ${ }^{(1)}$.

With a history of struggles, achievements and challenges that remain to this day, PR supported a new care model gradually adopted by the Brazilian mental health system that proposes people-centered care according to the patients' mental health needs and their reintegration into the community.

Support and follow-up at a community service permeate the different principles of the SUS and they are consolidated as a right. The provided psychosocial care network ("RAPS") connects different points of the health care system, regardless of technological complexity or density, in a range of decentralized services distributed across Brazil. The RAPS includes primary health care governed by the national policy of primary care ("PNAB") and consolidated by the family health strategy $(\mathrm{FHS})^{(2)}$.

The FHS became important in mental health care after PR promoted the deinstitutionalization of madness leading to a reduced number of beds at mental hospitals and a strengthening of the community care network. The FHS is widely available and easily implemented in Brazil, based on the guideline of longitudinal care, and it includes several practices that support mental health ${ }^{(3)}$, such as educational activities, group activities, medical consultations, home care ${ }^{(4)}$, creation of therapeutic projects, organization and ordering of care in the face of health services, among others. Furthermore, the FHS is generalist, free from the stigma caused by the removal of those who mental health care, commonly associated with classical psychiatric institutions ${ }^{(5)}$.

However, despite all its potentialities, longitudinal care has not been consolidated in the mental health care offered by the FHS. The predominant practices are medical consultations; medicalization of the subject and renewal of prescriptions from psychiatrists without confirming or assessing whether more medication is need; home visits and collective care, on rare occasions and therapy groups for mental health patients, where mechanisms are often adopted to facilitate switching of prescriptions without providing the collective space they needed to discuss doubts or health promotion ${ }^{(6-7)}$.

Primary care offers a range of mental health possibilities, such as therapeutic follow-up, community therapy and therapy groups, that require light health care technologies professionals must learn to use for psychiatric conditions in addition to seeking care actions and managing psychosocial problems based on comprehensiveness and matrix support ${ }^{(6)}$.

Considering the many demands related to mental health in primary care and its potentialities and responsibilities within the RAPS, it is important to assess and rethink mental health practices in the FHS. Experiences in the described scenario, with the predominance of fragmented actions based on medicalizing suffering, motivated the implementation of a mental health therapy group in an FHS and the realization of this research.

The assumption of the present study is that mental health therapy groups, which promote psychic intervention, can effectively monitor people with psychological distress or a mental disorder. Therefore, the present study is guided by the following research question: how can a mental health therapy group help to monitor users with psychological distress in the context of primary care?

Consequently, the aim of this paper was to understand the perception of primary care users in the face of mental distress and their participation in a therapy group.

\section{METHODS}

This is a qualitative study based on the methodological framework of Convergent Care Research ("PCA"), which primarily enables the joint development of scientific and care research actions. This approach allows immersion of the researcher in data collection driven by the commitment to study and operate in practice, making changes and introducing innovations, in order to elaborate knowledge that improves care practices. PCA is divided into four stages, namely conception, instrumentation, perscrutation and analysis ${ }^{(8)}$.

In the conception phase, the research theme was defined and the literature search was initiated to obtain theoretical and methodological support for the study. In the instrumentation phase, the site, participants, intervention proposal and data collection techniques were defined. The perscrutation stage consisted of interconnecting the instrumentation and analysis stages and translating them into rigorous investigation, from the choice of the data collection technique to the proposition and determination of inferences. Data analysis consisted of apprehension, 
synthesis and theorization, including apprehension of the information obtained during the interviews and interview encoding and involving the theoretical-conceptual formulations to understand the object of study in the theorization process.

The scenario was an FHS in Rondonópolis, a municipality in the southern microregion of the state of Mato Grosso, with 4,928 registered users. The connected territory is divided into seven micro areas, two of which are not monitored by a community health worker (CHW). In addition to the minimum team professionals, the unit has three residents of a family health residency program (nurse, pharmacist and psychologist).

The situational diagnosis at the start of the residency program revealed that approximately $7 \%$ of the registered population used psychotropic medication and users constantly demanded to switch medication. Moreover, users did not have regular consultations and they frequently required follow-up with the multidisciplinary team once the residents were included in the team. This context motivated the implementation of the therapy group as a therapeutic intervention for monitoring users in psychological distress.

Groups help maintain biopsychosocial balance, reduce personal conflicts, facilitate socialization and enable people to share their stories of life, suffering and overcoming, which helps them accept differences ${ }^{(9)}$.

The group conducted a range of activities every fortnight although it does not have a fixed number of meetings. During the meetings, the activities were aligned to the needs of the participants with the aim of ensuring they feel included and free to make decisions; the participants themselves named the group "infinity". Media resources (videos), music and dynamics were used to trigger discussions. On some occasions, they also did crafts and physical activities, such as stretching and walking.

The main purpose was to ensure comprehensive care for users, promote autonomy, improve the self-image of the group, provide opportunities for the free expression of participants, strengthen the bond with health workers and broaden access to services offered in the health system and in the community.

The group was intended for users enrolled in the health unit who suffered from some form of mental distress and who were undergoing drug treatment or not, and to their relatives, averaging six participants per meeting. Most users did not have a final diagnosis of a mental disorder. Their needs were evaluated according to the demands presented to the team based on signs and symptoms related to psychological distress and behaviors that affected their welfare, social conviviality and performance of daily activities. The users were then invited to participate in the group.

Data were collected by means of semi-structured interviews with the users participating in the group, organized into two axes: defining and describing psychological distress and evaluating participation in the therapeutic group. All the interviews were conducted between February and March 2018, totaling nine meetings, and they were audiotaped and transcribed in full. The inclusion criteria were 18 years or older, users enrolled the service and users considered members of the group. The exclusion criteria were users who had attended only one or two meetings and users who were not considered members of the group.

Of the users who participated in the meetings, four met the inclusion criteria and attended assiduously, so they were invited to participate in the research. These users were approached individually in the health unit and informed about the research. The scheduled interviews took place at their homes or at the unit itself, according to the user's preference. All the interviews were conducted by the resident nurse and lasted on average 40 minutes. None of the invited users refused to participate in the study.

Data analysis followed the proposed processes for $P C A^{(8)}$ previously presented. To encode the data in the synthesis stage, we used hierarchical descending classification ("CHD") with software Interface de R pour les Analyses Multidimensionnelles de Textes et de Questionnaires (IRAMUTEQ). $\mathrm{CHD}$ classifies the text segments according to their respective vocabularies and then divides them into classes with similar vocabulary respecting the frequency of the lemmatized words by repeatedly crossing the word matrices and applying chi-square-type tests. It then creates an interface to localize each word in the textual corpus and identify its context for qualitative analysis.

The project was approved by the Research Ethics Committee ("CEP") of the Federal University of Mato Grosso University Campus of Rondonópolis, under substantiated opinion No. 2.230.468 (CAAE: 72511417.0.0000.8088). The ethical and legal precepts of resolution No. 466/2012 of the National Health Council were respected and data collection was initiated only after the project was approved by the CEP. The research was conducted with the consent of the health department of the municipality. All participants were informed about the objectives of the study and the adopted collection technique and they signed an informed consent form. 


\section{RESULTS}

Four women participated in the interviews and they are characterized in Chart 1. Participant 1 denied she having a diagnosis of mental disorder but reported a history of secondary depression associated with a chronic condition, for which she used anxiolytic. Participant 4 denied having a mental disorder and did not use psychotropic drugs, however, she showed interest in group activities and her statements revealed that the activities she participated in helped protect her health. The participants had a low level of schooling and mostly had primary school education. They were all homemakers and three mentioned they did informal work, such as sell beauty products, homemade foods and crafts.

\begin{tabular}{|l|c|c|c|c|c|}
\hline Participant & Age & Education & Profession & Diagnosis & Use of psychotropic drugs \\
\hline $\mathbf{1}$ & 57 & Elementary & Homemaker & Denies current diagnosis & Yes \\
\hline $\mathbf{2}$ & 46 & Elementary & Homemaker & Depression & Yes \\
\hline $\mathbf{3}$ & 66 & Illiterate & Homemaker & Depression & Yes \\
\hline $\mathbf{4}$ & 70 & Secondary & Homemaker & None & No \\
\hline
\end{tabular}

Chart 1 - Characterization of the study participants. Rondonópolis, Mato Grosso, Brazil, 2018 Source: Research data, 2018.

\section{Subcorpus B}

Perceptions related to mental distress and the therapy group

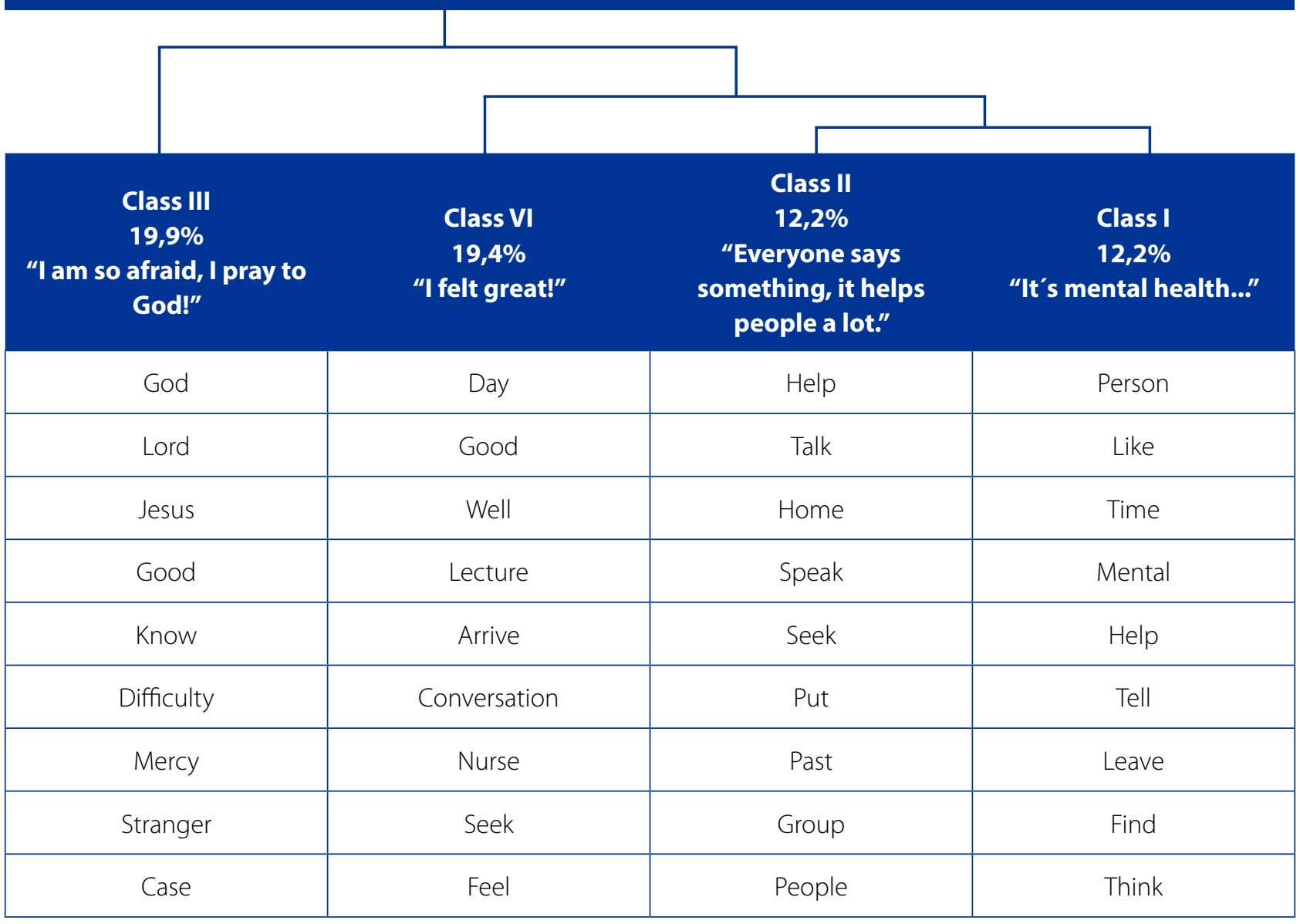

continue... 


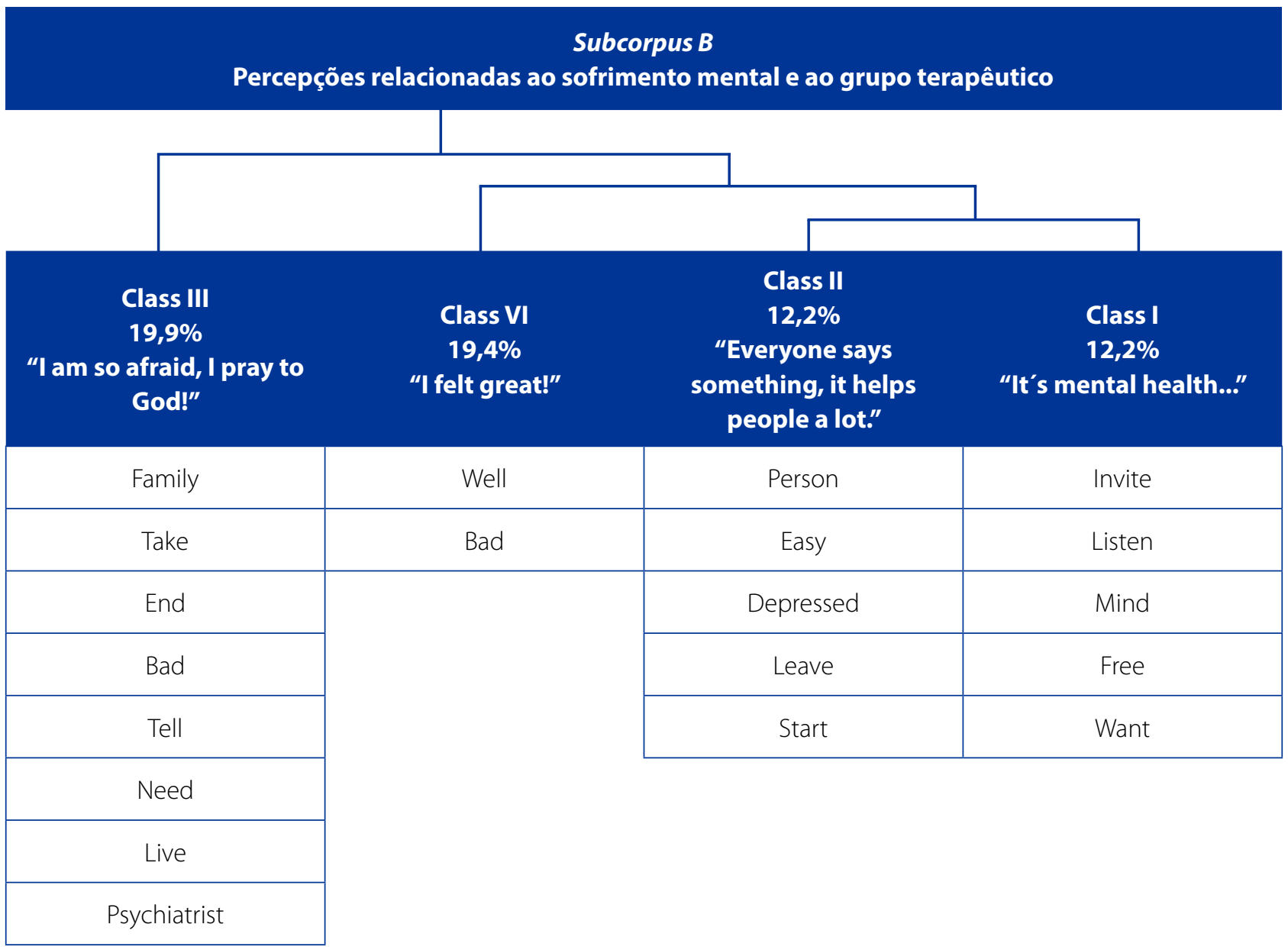

Figure 1 - Dendrogram resulting from the descending hierarchical classification of content submitted to analysis using IRAMUTEQ.

Source: Authors, observing software trends.

The database obtained with the interviews was encoded using IRAMUTEQ software, resulting in a general corpus consisting of four texts separated into 231 segments of text (ST), with use of 196 ST (84.85\%). In all, 9,430 occurrences emerged, of which 1,376 were different words and 681 occurred only once. The corpus in analysis was divided into two subcorpus ( $A$ and $B$ ), composing a dendrogram with the following classes: Class I, with 24 ST (12.24\%); Class II, with 24 ST (12.24\%); Class III, with 39 ST (19.9\%); Class IV, with 39 ST (19.9\%); Class V, with 32 ST (16.33\%); Class VI, with 38 ST (19.4\%).

Subcorpus A was called "Factors related to mental illness" and consisted of classes IV and V, while subcorpus B was called, "Perceptions related to mental distress and the therapeutic group" and consisted of classes I, II, III and VI. In this article, the results related to subcorpus B will be presented and discussed (Figure 1), since it corresponded to the objective of the study and shed light on the perception of participants regarding the difficulties of mental distress and participation in the group, revealed as the results are demonstrated.

The classes were named using statements that represent the participants. They are not in numerical order, but according to their proportion in the textual corpus, as encoded by the software.

\section{Class III: "I am so afraid, I pray to God!"}

In this class, the words God, Jesus and Lord, related to the religiosity of the users, were identified in two different semantic fields. First, they were mentioned as a supplication for the deliverance of a mental disorder; secondly, as a resource that can serve as support for suffering.

Lord of glory, I can't even explain to you why I'm so afraid, it's a disease that I'm so afraid of, so afraid, I pray to God. (Participant 1)

I have faith, I trust in God. (Participant 2) 
I got it with God and the doctor, in the church too [...]. (Participant 3)

The words know, difficulty, stranger, tell, need and psychiatrist were mentioned in relation to the fear of getting ill and the need to seek help or talk about their lives with another person, considered strange, which may hinder the mental health care.

I resisted [...] I will tell my life to a stranger, you have that difficulty, you do not know the person [...]. (Participant 1)

Ah, but psychiatrist oh, but psychologist is for crazy people, I am not crazy [...]. (Participant 1)

The stigma of madness or the idea that psychology and psychiatry are for "mad" people caused insecurity and resistance to care. In this aspect, the therapeutic group can assist in coping with this stigma by promoting discussions on the subject.

\section{Class VI: "I felt great!"}

This class allows the identification of user statements on how "good" or "well"they felt when participating in therapy group activities, recognized in the textual corpus from the words day. arrive, lecture, conversation.

It is good, we have a good, really calm day [...]. (Participant3)

I feel so relieved [...] very good, people feel good and say that when they go there they feel stronger, more lively. (Participant 4)

The receptiveness appeared in the speech of one of the participants, qualified by the adjective "nice":

[...] I was quite ill, dying to go back running to those people, I did not want to see anyone, then a person went there and offered to help, nice [...]. (Participant 1)

In this statement, offering to help or provide support is perceived as a very important technology for mental health care and it proved essential for users to feel good, connected to the group and willing to participate in the activity.

\section{Class I: "It's mental health..."}

The most frequent word in this class was "person". Further analysis revealed that this person is the self and the person who suffers, participates, invites, needs help, gets annoyed, says no and has desires; the agent involved in several processes, including those related to the mental health therapy group.

In this class, the mental health therapy group has the potential for promotion and prevention in mental health.

[...] many things, we do not open up at home, we communicate here with the group [...] we communicate a lot with others, see that it is not only me that has problems, other people also have problems and need help. (Participant 2)

Sometimes the person can be going through something, so they do there and they leave feeling lighter. (Participant 3)

It can help a lot because there you teach people to work with their mind, develop the mind [...] it is mental health, this group of mental health is good. (Participant 4)

The statement that provides the title to this class is participant four, who did not have a diagnosis of mental disorder and did not use psychotropic drugs. The words "develop the mind" can be understood as promoting mental health and demonstrates group's potential as a form of intervention, not only for users with current complaints that characterize psychological suffering but also to promote the health of those who are interested in these activities.

Also in this class, the word mental once again reflects the stigma perceived by the users, including as an impeditive to participation in the group.

Is the mental you are talking about people who are little weak in the head? (Participant 2)

Many say I will not go because I do not have a mental problem. (Participant 4)

The data show the effects that the stigma related to mental illness has on society, preventing many people from seeking care, and may justify the low number of participants in the therapy group.

\section{Class II: "Everyone says something, it helps people} a lot."

As the group develops, dialog and listening are perceived as instruments of work and therapeutic elements. These elements were beneficial for group participation and mainly identified from the words say and talk.

We started listening, then one says one thing, says another and leaves the place feeling like a new person, I got home feeling good, I was cheerful. (Participant 3)

You have talked about more stuff, your group has had other dialogues, each person says something. (Participant 3 )

The absence of dialogue was also associated with the illness, in the sense that the person in mental distress or "depressed" does not "talk", does not "communicate".

[in] depression the person gets depressed, gets sad, does not communicate [...] keeps quiet, does not talk too much, only talks if you ask them something, otherwise they do not speak. (Participant 4).

The results presented show that the collective relationship built in the group is therapeutic because, unlike the 
idea of suffering in silence, they have the opportunity to talk about this suffering and to listen to others, which is not always possible in other contexts. Moreover, when the participants shared their experiences and knowledge, the intervention of the professionals was often expendable.

\section{口DISCUSSION}

Each year, millions of people become mentally ill and many, especially those who have been institutionalized and/or hospitalized, are considered invalid, demoralized or hopeless, revealing the historically constructed stigma is still a current problem, which only worsens the depression and self-deprecation of people in psychological distress ${ }^{(10)}$.

Historically, mental illness was seen as divine punishment and treated through rituals to expel evil from the soul and decontaminate the families, thus contributing to the stigmatization of madness and the exclusion of those who did not comply with social standards ${ }^{(10-11)}$.

Contrary to these conceptions, PR is a complex social movement that opposes the asylum and hospital-centered model and seeks to redefine the social relationship with madness by re-inserting people with mental illness in the community, thus causing a rupture with the history of psychiatry and a confrontation with the social stigma built over time ${ }^{(12)}$.

However, the data of this study demonstrate that, despite the efforts of PR and the changes achieved through RAPS, the stigma regarding mental illness is still a problem that aggravates the health status of those with mental illness or psychological distress who need care with health workers, as observed in the speeches of classes I and III.

The statements regarding the religiosity of users reveal they are afraid of becoming mentally ill or of being seen as crazy or incapable, which leads them to pray to God for deliverance from the disease, referring to the historical construction of madness. However, religiosity is identified as a means for personal wellness and can be encouraged by health workers as a resource for care and health promotion and to prevent isolation and greater adequacy in face of the adversities of life ${ }^{(13)}$.

The still present fear and stigma related to mental illness justify the need for integrating mental health and primary care and, consequently, reduce the stigma with a more generalist and integrated scenario of these services and attract the patients and relatives concerned with this stigma ${ }^{(5)}$. Such a scenario also reinforces the importance of studies that address the subject in a practical way and depict interventions implemented in the FHS, as we sought to present in this study, to encourage and guide workers in this area and renew mental health practices.
In this scenario, the therapy group is a psychosocial intervention that helps patients cope with the stigma by proposing discussion, assisting people with different singularities in a common territory and providing a therapeutic and educational service to complement several aspects of the work with mental health groups in primary care ${ }^{(14)}$.

Reducing the stigma can increase tolerance and acceptance of everything that is different, promoted by group conviviality and the sharing of experiences for personal growth ${ }^{(9)}$. Another way the group can reduce the stigma is by socializing people in psychological distress with the community since it was open to everyone, especially during the stretching and walking activities, as seen in another study ${ }^{(15)}$.

Regarding the feelings reported by the users regarding their participation in the group, shown in class VI, the meetings are opportunities to learn and make significant life changes given the collective relationship of the therapy instrument whereby the sharing of ideas and feelings leads to an individual resignification of the suffering that occurs in the presence of the other, that is, in coexistence ${ }^{(14-15)}$. The group process allows an exchange of experiences and subjective transformations that could not be achieved in individualized $\operatorname{car}^{(5)}$. These characteristics of the therapy group certainly refer to the feelings of wellness, relief and encouragement mentioned by the users, which were only possible when meeting with other participants.

Any health care approach includes the meeting of people who work with each other through relational or light technologies, such as receptive assistance, bonding, communication and trust, all of which are essential tools for mental health care ${ }^{(14,16)}$ as shown in this study, especially in classes I and II.

With regard to receptive assistance, stressed in one of the statements, every meeting between professional and user occurs through technological processes, within the realm of relational technologies, including receptive assistance, without which bonding, accountability and, consequently, problem-solving in health promotion would not be possible ${ }^{(16)}$. As perceived in the statements of the participant in this study, receptiveness occurred and was paramount for her to face her difficulties and seek professional assistance for her health condition. It is also noteworthy that receptive assistance can be provided by any health worker and it enables greater problem-solving capacity to the team in the case of users who need psychosocial support ${ }^{(15)}$.

These relational technologies were essential for the group to advance and bond because the receptiveness encourages the user to accept the invitation to participate in the group and the communication, dialogue and 
exchange of experiences strengthened the bond and trust. Therefore, the users felt confident and comfortable enough to talk about their anguish and suffering, which promotes wellness and prevention in mental health, as highlighted in class II. The moments of talking, listening and interpretation are created between people who feel welcome and support in the meeting and allow for complicity, accountability, trust and hope ${ }^{(17)}$, clearly perceived in the group's movements and expressed in the user statements.

Finally, dialogue must be presented as guiding axis of the group process, as found in another study on groups and mental health promotion ${ }^{(18)}$, Furthermore, users can feel included in a relationship with open communication channels and feel part of a group where they can talk about their feelings, once hidden under the symptom, and increase their autonomy $y^{(3,18)}$. We agree, then, that effective care is only possible by constructing a dialogical relationship between user-user and user-professional and, therefore, learn about the reality and needs of each individual and raise the level of mental health care to a more comprehensive level(3).

Considering the need for a dialogical relationship to improve mental health practices in primary care and that this construction is possible when workers and user coexist in the group, the choice of PCA was critical as a referential methodological framework for this study and it established the researcher's involvement in care. Therefore, as researchers involved in the care context, the residents were able to experience this construction and all the feelings and movements expressed by the group verified in the results, which, throughout the entire process, contributed to their vocational training.

\section{口 FINAL CONSIDERATIONS}

The stigma related to mental illness is a persistent problem and obstacle for people to seek appropriate help or treatment for their condition, as demonstrated in this study.

The perceptions of the participants about mental distress and the therapeutic group revealed that it is possible to reduce the stigma by promoting tolerance, involving people in psychological suffering with the community, enabling the sharing of feelings and discussing this theme in a generalist and prejudice-free scenario. In addition, the therapy group and its benefits support prevention and the promotion of mental health through low-cost, relational technologies accessible to all workers.

The therapy group of coexistence is a collective psychosocial intervention that can benefit the participants and professionals involved. Furthermore, it may help reduce the demands for individualized care and constitute an environment where the attentive professional can identify specific demands and perform equally significant actions to promote health and prevent aggravation, which is not always possible in individual care due to the limited time available.

The limitation of this study and the difficulty in forming the group in primary care are the small number of participants, which may be a consequence of the stigma related to mental illness and the problems FHS workers had in effectively participating in the activity and accepting the demands of mental health. In contrast, the small group can also be an advantage since it could be perceived as protected or safe, thus favoring dialogue and exchanges among its participants.

The study is relevant for nursing professionals and workers of other health care areas because it reveals aspects that enable therapy groups in primary care, inspire new actions and revitalize mental health practices in a context where fragmented conduct is predominant. It can also contribute to the professional training of researchers directly linked to the care practice when the study was conducted.

\section{口 REFERENCES}

1. Amarante $P$, Nunes MO. A reforma psiquiátrica no SUS e a luta por uma sociedade sem manicômios. Ciênc Saúde Coletiva. 2018;23(6):2067-74. doi: https://doi. org/10.1590/1413-81232018236.07082018

2. Ministério da Saúde (BR). Portaria n³.088, de 23 de dezembro de 2011. Institui a Rede de Atenção Psicossocial para pessoas com sofrimento ou transtorno mental e com necessidades decorrentes do uso de crack, álcool e outras drogas, no âmbito do Sistema Único de Saúde (SUS). Diário Oficial da União [da] República Federativa do Brasil. 2011 dez 30;148(251 Seção1):59-61.

3. Silva GD, Iglesias A, Dalbello-Araújo M, Badaro-Moreira MI. Práticas de cuidado integral às pessoas em sofrimento mental na atenção básica. Psicol Ciênc Prof. 2017;37(2):404-17. doi: https://doi.org/10.1590/1982-3703001452015

4. Camatta MW, Tocantins FR, Schneider JF. Ações de saúde mental na Estratégia Saúde da Família: expectativas de familiares. Esc Anna Nery. 2016 [cited 2019 May 17]; 20(2):281-8. Available from: http://www.eean.edu.br/detalhe_ artigo.asp?id=1394

5. Wenceslau LD, Ortega F. Saúde mental na atenção primária e Saúde Mental Global: perspectivas internacionais e cenário brasileiro. Interface (Botucatu). 2015;19(55):1121-32. doi: https://doi.org/10.1590/1807-57622014.1152

6. Gryschek G, Pinto AAM. Saúde Mental: como as equipes de Saúde da Família podem integrar esse cuidado na Atenção Básica? Ciênc Saúde Coletiva. 2015;20(10):3255-62. doi: https://doi.org/10.1590/1413812320152010.13572014

7. Yoneyama BC, Esteves RZ, Maruiti AMP. Um olhar sobre os usuários de medicamentos psicoativos acompanhados na Atenção Primária em Saúde em Maringá-Paraná. Espaço Saúde. 2016 [cited 2018 0ct 31]; 17(1):114-20. Available from: http://espacoparasaude.fpp.edu.br/index.php/espacosaude/article/view/375

8. Trentini M, Paim L, Silva DMGV. Pesquisa convergente assistencial: delineamento 
provocador de mudanças nas práticas de saúde. 3. ed. Porto Alegre: Moriá; 2014.

9. Nogueira ALG, Munari DB, Fortuna CM, Santos LF. Pistas para potencializar grupos na Atenção Primária à Saúde. Rev Bras Enferm. 2016;69(5):964-71. doi: https://doi.org/10.1590/0034-7167-2015-0102

10. Winn JS. An existential-phenomenological investigation of the experience of being accepted in individuals who have undergone psychiatric institutionalization. Indo-Pac J Phenomenol. 2016;16(supl1):1-14. doi: https:// doi.org/10.1080/20797222.2016.1164992

11. Tanaka C, Tuliao MTR, Tanaka E, Yamashita T, Matsuo H. A qualitative study on the stigma experienced by people with mental health problems and epilepsy in the Philippines. BMC Psychiatry. 2018; 18:325. doi: https://doi.org/10.1186/ s12888-018-1902-9

12. Amarante $P$, Torre EHG. Loucura e diversidade cultural: inovação e ruptura nas experiências de arte e cultura da Reforma Psiquiátrica e do campo da Saúde Mental no Brasil. Interface (Botucatu). 201721(63):763-74. doi: https://doi. org/10.1590/1807-57622016.0881

13. Nery BLS, Cruz KCT, Faustino AM, Santos CTB. Vulnerabilidades, depressão e religiosidade em idosos internados em uma unidade de emergência. Rev Gaúcha Enferm. 2018;39:e2017-0184. doi: https://doi.org/10.1590/19831447.2018.2017-0184
14. Ministério da Saúde (BR), Secretaria de Atenção à Saúde. Saúde Mental. Brasília (DF): Ministério da Saúde; 2013 [cited 2019 Feb 10]. Caderno de Atenção Básica n. 34. Available from: http://bvsms.saude.gov.br/bvs/publicacoes/cadernos_ atencao_basica_34_saude_mental.pdf

15. Minóia NP, Minozzo F. Acolhimento em saúde mental: operando mudanças na Atenção Primária à Saúde. Psicol Ciênc Prof. 2015;35(4):1340-9. doi: https:// doi.org/10.1590/1982-3703001782013

16. Franco TB, Bueno WS, Merhy EE. 0 acolhimento e os processos de trabalho em saúde: 0 caso de Betim, Minas Gerais, Brasil. Cad Saúde Pública. 1999;15(2):34553. doi: https://doi.org/10.1590/S0102-311X1999000200019

17. Merhy EE. 0 ato de governar as tensões constitutivas do agir em saúde como desafio permanente de algumas estratégias gerenciais. Ciênc Saúde Coletiva. 1999;4(2):305-14. doi: https://doi.org/10.1590/S1413-81231999000200006

18. Dutra WH, Corrêa RM. 0 grupo operativo como instrumento terapêuticopedagógico de promoção à saúde mental no trabalho. Psicol Ciênc Prof. 2015;35(2):515-27. doi: https://doi.org/10.1590/1982-370302512013
Corresponding author:

Naipy Abreu Brunozi

E-mail: nabrunozi@hotmail.com
Received: 03.29.2019

Approved: 06.05.2019 